\title{
Depiction, Perception, and Imagination: Responses to Richard Wollheim
}

Richard Wollheim holds, famously, that pictorial representation is to be understood in terms of a visual experience of a special kind, which he calls "seeing-in," an experience that suitable spectators enjoy when they look at pictures. On viewing a picture of a fire engine, one sees a fire engine in the marks on the surface of the picture. I have argued that pictures are essentially props in visual games of make-believe of a certain kind, and that the crucial perceptual experience -which I am happy to call "seeing-in"-is an imaginative as well as a perceptual one. The viewer imagines seeing a fire engine as she looks at a picture of one, imagining her actual visual experience to be of a fire engine. Wollheim and I have carried on an intermittent dialogue in the course of developing and explaining our respective theories of depiction, commenting on one another's views and on the relations between them. I continue the dialogue in this essay, concentrating now on Wollheim's "On Pictorial Representation," the most recent statement and defense of his theory, as well as his Painting as an Art. ${ }^{1}$

I

Wollheim endorses (with minor reservations) Alberti's observation that "the painter is concerned solely with representing what can be seen," which he takes to express a constraint on the scope of representation: only what is visible can be represented. ${ }^{2}$ The seeing that Alberti has in mind is, surely, ordinary visual perception of particular existing objects (or events), what we might call seeing things "face-to-face."

The things that can be seen and so can be represented, Wollheim observes, include both objects and events. Some of them are particular objects or events, while others are "objects or events merely of a particular kind." "So we can have a representation of Madame Moitessier" (Ingres's 1851 portrait), "or a representation of a young woman behind a bar, perhaps a young woman of some specificity-but no particular young woman" (Eduard Manet's La Prune, c. 1877). ${ }^{3}$

Is what is represented, in the latter case, something that can be seen? I would expect Alberti to point out that it is possible to see particular existing things of this kind, actual young women behind bars, even though nothing would count as seeing (face-to-face) "the woman in the picture," the woman the picture represents. And I expect that he would take this to satisfy the principle that painters are "concerned solely with representing what can be seen." What cannot be represented (pictured) are presumably things such as the average price of oil in the 1970s, magnetic fields, and Cartesian egos. ${ }^{4}$

Wollheim chooses not to understand the constraint on what can be represented in this manner. There are two different ways of seeing things, he explains: one can see things "faceto-face," and one can see things "in a marked surface." Some things can be seen only in the second manner, but that is all that is required for them to be representable. "Representation does not have to limit itself to what can be seen face-to-face: what it has to limit itself to is what can be seen in a marked surface". 5 Objects or events that are "merely of a particular kind" are among the things that can be seen in a marked surface but not face-to-face, Wollheim claims. So the nonparticular woman represented by $L a$ Prune is representable not because particular things of that sort can (could) be seen faceto-face, but because this nonparticular one can be seen "in a marked surface." 
Wollheim appears committed to the view that there really are nonparticular women (and nonparticular battles, etc.) —special kinds of things that can be seen in a special way. It is not clear how serious he means this commitment to be. ${ }^{6}$ But it is not clear, either, what alternative he would endorse, or what alternatives are open to him. People do sometimes speak of "seeing pink elephants," arguably without implying that there are any such. (One might question whether this is a literal use of "see"; I prefer to think of it as short for "seem to see.") But Wollheim obviously does not regard seeing-in as hallucinating, as a kind of visual illusion, and he is obviously right not to do so. ${ }^{7}$

Are his nonparticular women fictional entities? If so, the puzzles about their ontological status are familiar, at least (even more familiar than those concerning objects of hallucinations). And some, I among them, would argue that we need not suppose that there really are such things while acknowledging, indeed insisting on, the convenience of speaking as though there are. I would expect Wollheim to be unsympathetic to this suggestion, as it encourages regarding imagination as more central to depiction than he seems willing to allow. But in Painting as an Art he is amenable to construing "There are peasants there" uttered in front of a picture of haymakers as an "exercise in make-believe."

He sharply contrasts "There are peasants there" with "I see peasants" (also uttered in front of the picture of haymakers), however, insisting that the latter expresses "a genuine perceptual judgment" not involving make-believe. ${ }^{9}$ This sharp contrast is intuitively unattractive, to say the least, especially since the peasants that one "sees" are surely (as it were) none other than the ones that are "there." It is not clear how Wollheim will account for the naturalness of comments such as, "There are peasants there, whom I see" and "There are peasants there; I can see them." He wants to insist on the fact that the viewer enjoys a genuine visual experience, which grounds the visual nature of depiction, not just an imaginary or make-believe one. But this fact is in no danger, not on my account in any case. For although I deny that the viewer's experience is, literally, one of seeing peasants, it is an actual visual experience. What is merely imagined is that this visual experience has peasants as its object.
So why not allow that "There are peasants there" and "I see peasants" both involve makebelieve? To return to Manet's La Prune, we imagine seeing a woman whom we imagine to be there. This makes life a lot easier. For the seeing that I merely imagine being engaged in is perfectly ordinary, face-to-face seeing, and it is seeing of a perfectly ordinary, particular woman, indeed an existing one - that being the only kind of woman there can be. There is no need to recognize seeing of a special kind, directed on a peculiar and otherwise unseeable object. ${ }^{10}$ I do (genuinely) enjoy a special kind of visual experience, but it is one that is understood in familiar terms -in terms of really seeing the picture surface (face-to-face) and imagining this seeing to be of a woman (an ordinary one). Viewers of the portrait of Madame Moitessier enjoy an experience of just this kind also; the only difference being that in that case there is a woman whom one imagines seeing.

The reader will have noticed that, although Wollheim takes La Prune to represent a woman "merely of a particular kind," there is an obvious sense in which it represents a perfectly ordinary, particular woman, or (this may or may not amount to the same thing) it represents a woman as being perfectly ordinary and particular. Put differently, the woman "in the world of the picture" is, in that world, an ordinary particular woman-indeed an existent one. This observation is awkward for the proponent of seeing-in as Wollheim characterizes it. Conceivably, he might stick to his guns, reiterating that what is represented, what a (suitable) perceiver sees in the marked surface, is actually a woman "merely of a particular kind," while allowing that the perceiver sees this nonparticular woman (in the marked surface) as a particular one. The picture would thus be understood to misrepresent a woman merely of a particular kind as being a particular woman. We need not dwell on the unattractiveness of this suggestion.

I claim a further advantage for my way of dealing with what Wollheim calls depictions of things "merely of a certain kind": It generalizes readily to works other than pictures. Stories and novels often portray "nonparticular" persons and "nonparticular" objects and events of other sorts, in whatever sense La Prune does. There is no special visual experience, "seeing-in," which takes such things as objects. Are they objects of 
a special experience of reading, one we might call "reading-in," or "reading about-in", even though they cannot be read about in the ordinary manner-presumably the manner in which we read about actual people in newspapers?

It is far better to say that readers of novels and stories imagine ordinary particular people. Sometimes they imagine reading, in an ordinary newspaper manner, about such people. Often (depending on the nature of the story or novel) they imagine hearing verbal reports of them, or learning about them, or anyway knowing about them. What is imagined is in any case (exotic examples aside) ordinary things cognized in ordinary ways. ${ }^{11}$

II

In his marvelously rich and perceptive explorations of pictorial representation, Wollheim has surprisingly little to say about the perspectives or points of view from which things are depicted. He distinguishes between the foreground and the background of various paintings, this being, of course, a matter of the pictures' perspectives. ${ }^{12} \mathrm{He}$ describes the fundamental experience of seeing-in as seeing one thing in front of another. ${ }^{13} \mathrm{He}$ notes that in Nicolas Poussin's Rinaldo and Armida, Rinaldo's "face is somewhat turned towards us." 14 But he does not, so far as I know, spell out what it is for a depiction to be from one point of view rather than another, or as we sometimes put it, what it is to depict something as seen from a certain perspective. How might he do this?

It is safe to assume that he would want to account for this in terms of the visual experiences of suitable observers; so do I. His comment about Rinaldo's face being turned toward us comes in a paragraph describing "what we see" in the picture. So perhaps a picture's depictive point of view consists in what the suitable spectator sees in it. ${ }^{15}$ How can this be? What we see in the picture is Rinaldo and various of his properties - the position of his head and arm relative to his body, his being asleep, etc. The perspective is not among his properties. He does have relational properties that we see-his head being turned away from Armida, for instance, whom we also see in the picture, a property that is not constitutive of the picture's perspective. Wollheim says that Rinaldo's head is turned slightly toward us.
Do we see this relational property in the picture surface? We do not see ourselves in it, obviously. Do we see Rinaldo turned toward observers (ourselves?) who, although not themselves seen in the picture, are understood to be "there"? Wollheim does allow that certain paintings have "a representational content in excess of what they represent," of what can be seen in them; there may be a figure "in the represented space [but] not the part of it which is represented." 16 In some cases there are unrepresented spectators, what he calls the "spectator in the picture," whom the viewer, the spectator of the picture, identifies with, imagines from the inside. ${ }^{17}$ But even in these cases the viewer is not part of the representational content of the picture, not in the represented space; 18 she merely identifies, imaginatively, with someone who is. And most pictures do not contain a spectator in the picture anyway. ${ }^{19}$ Yet most or all pictures depict things "from a certain point of view." 20 I do not see how this can be explained in terms of what is seen in the picture. ${ }^{21}$

The perspective from which one sees something, in cases of ordinary visual perception, is a matter of the point in space, relative to the object seen, from which one sees it. (This usually has consequences for what is seen, of course. But it would be a mistake to identify the experience of seeing from a particular perspective with the properties of the thing that one sees.) The viewer of Rinaldo and Armida is actually at a certain place relative to the picture-seven feet from it and slightly to the left of center, for instance. It is from this position that one sees Rinaldo in the picture surface. But this location in space does not correlate with one's perspective on Rinaldo in the sense in which "his face is turned toward us," the sense in which it is the perspective from which he is depicted. To change one's position relative to the canvas, to move closer to it, for instance, or farther to the left, does not affect one's point of view in the latter sense. (This is why we can say that the picture depicts Rinaldo from a certain point of view; we cannot normally say this about freestanding sculpture.)

Shall we say that the markings on the canvas are such that, from wherever the viewer is actually positioned, what she sees in the picture surface is Rinaldo-from-a-certain-angle-anddistance? It is not clear what this might mean. And the angle and distance from which (in some 
sense) she sees Rinaldo, in the picture, is in any case not her actual perspective or point of view-not in anything like the sense of perspective that applies to ordinary vision. Wollheim insists that the viewer actually sees Rinaldo, but it is unclear how this seeing-in can actually be from a certain perspective, apart from the ordinary perspective one has on the picture itself.

The solution is staring us in the face: On looking at the picture one imagines seeing Rinaldo from a certain (approximate) angle and distance. ${ }^{22}$ This, curiously, is what Wollheim seems to be saying about the special case of pictures that possess a "spectator in the picture." The viewer identifies with this personage, and so imagines seeing what he sees from his perspective. Why cannot the viewer imagine seeing the depicted objects from a given perspective without having such a spectator to identify with? Otherwise, the obvious fact that most or all pictures depict things "from a perspective or point of view" remains mysterious.

\section{III}

The upshot of these several worries is that Wollheim's characterization of seeing-in, of the experience of picture perception, is seriously incomplete. One way to indicate what is missing, while sidestepping any misunderstandings that may arise from different conceptions of the imagination, is to observe that there is no place, or no obvious place, in his account of the content of the viewer's experience for anything like the thought or idea or impression or awareness or conception or notion of an ordinary seeing of an ordinary woman. ${ }^{23}$ Instead, he has perceivers seeing objects of a different kind, in a special way. Perhaps if pressed, he would acknowledge some such thought or idea or impression. That would be a big step toward my way of understanding his notion of seeing-in, whether or not he agreed to speak of "imagining."

He does say that the recognitional aspect of seeing-in, when one sees a boy in a stained wall, for instance, is "capable of being described as analogous to" the experience of seeing a boy face-to-face. But he insists that the two sorts of experience are "phenomenologically incommensurate," and that it is a confusion to ask "how experientially like or unlike" the one is to the other. "We get lost once we start comparing the phenomenology of our perception of the boy when we see him in the wall ... with that of our perception of [the] boy seen face-to-face." 24 Insofar as I understand this, I think I agree. I take it to mean, roughly, that the two experiences differ not in "degree," but in "kind," that it is wrong or misleading to describe the experience of seeing-in or its recognitional aspect as an experience somewhat like that of face-to-face seeing (as some resemblance theories of depiction might have it). Wollheim constantly refers to seeing-in as a distinct kind of perception, or a visual experience with a distinctive phenomenology.

Agreeing with this does not require excluding the thought or impression of face-to-face seeing of a boy from the phenomenology of seeing a boy in the marks. Rather than being somewhat like engaging in face-to-face seeing, seeing-in is a visual experience that involves (as I choose to put it) imagining-merely imagining-doing so. And what is imagined is not just somewhat like face-to-face seeing, but the real thing. The difference between imagining seeing and actually doing so is, I take it, a difference in "kind." Malcolm Budd argues that if the two phenomenologies are incommensurate, the recognitional aspect of seeing-in cannot be understood on the analogy of face-to-face seeing. Hence, the "recognitional aspect of seeing-in . . . is revealed as having no nature of its own." 25 Understanding the recognitional aspect to involve imagining seeing makes sense of the claim that it is both analogous to and incommensurate with face-to-face seeing.

Wollheim urges that "there is an important causal traffic between seeing-in and seeing face-to-face. Children learn to recognize many familiar and unfamiliar objects through first seeing them in the pages of books." 26 This is no surprise on the imagining seeing account. It is a familiar fact of experience, confirmed by empirical research, that doing things in imagination can often improve one's ability to do them in fact. ${ }^{27}$ Imagining (visualizing) a face from a verbal description may help me to recognize it in the flesh. ${ }^{28}$

Jerrold Levinson has, inadvertently, provided support for my claim about the lacuna in Wollheim's notion of seeing-in. He claims to agree with Wollheim that "seeing-in is generally prior to, and not to be analyzed in terms of, imagined seeing." 29 But his discussion (sketchy 
though it is) suggests that he is thinking of this experience very differently from the way Wollheim does, and points strongly in the direction of the kind of imagining seeing I take to be central. 30

He makes a stab at clarifying the recognitional aspect of seeing-in: "In looking at a picture of a woman," he proposes, "it seems to you as if you are seeing a woman (alternatively, you have an impression of seeing a woman), in virtue of attending visually to portions of the canvas. The core of seeing-in . . . is a kind of as-if seeing that is both occasioned by and inextricably bound up with such registering." 31 To say that it "seems as if" something is the case often implies, perhaps even entails, that it is not the case; Levinson's stab thus appears to conflict with Wollheim's insistence that to see a woman in a picture really is to see a woman, though in a special manner.

The kind of seeing of a woman Levinson has in mind, the seeing it "seems as if" one engages in, is surely ordinary face-to-face seeing of an ordinary woman. Levinson thus brings on board exactly what I claim, most fundamentally, to be missing from Wollheim's account of seeing-in, the (unarticulated) thought or impression or idea of seeing an ordinary woman in an ordinary manner.

Why does Levinson deny that seeing a woman in a picture involves imagining seeing a woman face to face? In one discussion he simply declares that he finds it "odd" to say this, ${ }^{32}$ but a footnote to his essay on Wollheim reveals more: "On my conception of it, imagining is necessarily active or contributory. . . By contrast, seeming to one as if . . is passive or receptive, not something one brings about and actively sustains, but something that . . . simply occurs. Seeing $\mathrm{X}$ in $\mathrm{Y}$ is something that happens to one." 33 Since I have always insisted that the kind of imagining central to my theory can be and frequently is nondeliberate, something that happens to us (often as a result of prompting by a picture or other prop), his disagreement with my account turns out to be verbal rather than substantive. Understanding as if seeing as imagining seeing (in my sense), it is not hard to construe Levinson's suggestion that the viewer imagines seeing a woman "in virtue of attending visually to portions of the canvas" as the claim that the viewer imagines his seeing of the canvas to be a seeing of a woman. (Other construals are possible as well.)

Levinson does offer another reason for resisting analyzing seeing-in in terms of imagining seeing, but it backfires. If all seeing-in involves imagined seeing, he claims, "we lose a resource for explaining some of the special character, whether of immediacy, intimacy, absorbingness, or emotional impact, of some pictures as opposed to others." 34 I have identified enormous resources available to my theory for making distinctions of these kinds within the class of things serving as props in visual games of makebelieve-for accounting for differences of "realism," in several senses, among depictions, and for understanding different styles of depiction. The visual games in which pictures are props vary greatly in richness and vivacity. They are more or less indeterminate, in various respects. The principles of make-believe may or may not be linked to resemblances of one sort or another, and they may be internalized to different degrees. Some pictures restrict viewers' participation in the game, in one dimension or another. And so on. ${ }^{35}$ Levinson would forgo all of these resources for the sake of a simple crude contrast between inducing or not inducing perceivers to imagine seeing the object represented.

I claim support for my account of depiction, also, in a recent discussion by Catherine Abell and Gregory Currie. "Pictures aid the simulated seeing of their objects," they propose. "A depiction is an input to the simulation of seeing something." And they speak of simulations as involving "pretend perceptions." 36

IV

I turn now to objections Wollheim has raised to my theory of depiction.

In Painting as an Art, Wollheim claimed that my make-believe theory "holds that there is a conventional link between the appearance of the picture and what we are led to make-believedly see" and so fails to "ground what a painting represents in the kind of visual experience that the representation will cause" in suitable spectators. ${ }^{37}$ My reply is that (what I call) principles of generation or principles of make-believe are not in general "conventional" in any robust sense. In Mimesis I warned against characterizing them thus. ${ }^{38}$ Also, although the principles 
specify what imaginings are appropriate, given the nature of the props, appreciators do not usually consult them, or even have them in mind, in deciding what to imagine. Indeed, they usually do not decide what to imagine, but simply find themselves imagining in a certain manner, prompted by properties of the work before them. 39

The role of the principles of make-believe in my account is exactly analogous to that of Wollheim's own "standard of correctness" in his. Neither compromises the visual nature of depiction:

While a standard of correctness applies to the seeing appropriate to representations, it is not necessary that a given spectator should, in order to see a given representation appropriately, actually draw upon, rather than merely conform to, that standard of correctness. He does not, in other words, in seeing what the picture represents, have to do so through first recognizing that this is or was the artist's intention. On the contrary he may-and art historians frequently do-infer the correct way of seeing the representation from the way he actually sees it ... and, for a spectator reasonably confident that he possesses the relevant skills and information, this is perfectly legitimate. ${ }^{40}$

An entirely different objection, which Wollheim has advanced more recently, focuses on my claim that on viewing a picture of a fire engine, for instance, one imagines one's actual perceiving of the picture to be a perceiving of a fire engine. His argument consists of rhetorical questions:

My difficulty ... is how to understand the core project, or imagining one perceptual experience to be another. For if we succeed, in what way does the original experience retain its content? For, what is left of the experience of seeing the surface when I successfully imagine it to be some other experience? However, if I do continue to see the surface, or this experience retains its content, how have I succeeded in imagining it, the experience, to be an experience of seeing a face? ${ }^{41}$

He sees no difficulty, in general, in imagining one action or experience to be a different one. One may move one's hands in a jerky and irregular fashion, imagining this to be an action of conducting an orchestra. What he claims to find problematic is imagining of a perceptual experience of one kind that it is a perceptual experience of a different kind.

This does not seem to me to be a problem at all. Why should imagining a perceptual experience to have one content while recognizing that it actually has a different one be any more difficult than imagining an object to have properties different from those one realizes it really possesses - imagining a glob of mud to be a pie, for instance? I listen to a Glenn Gould recording of Bach's Art of the Fugue. My actual perceptual experience is of sounds emanating from a speaker in my living room, but I imagine my experience to be of a live performance in a concert hall. ${ }^{42}$ Attending a performance of Die Zauberflöte, I hear the sounds produced by the flutist in the pit orchestra, imagining my experience to be of sounds produced by Papageno with his crude wooden instrument.

Patrick Maynard reminded me that Scottie, in Hitchcock's Vertigo, dresses up Judy precisely in order to enjoy a vivid imaginative experience of perceiving the now deceased woman he knew as Madeleine. Surely Scottie's actual experience remains one of perceiving the dressed-up Judy; and surely he imagines this experience to be one of perceiving Madeleine. Never mind that Judy turns out to be Scottie's Madeleine. Scottie's imaginative project as he conceived it, believing Judy and Madeleine to be different persons, is perfectly coherent.

It is surely coherent, also, to suggest that in interacting with her husband or her boss a person might, perhaps unconsciously, imagine herself to be interacting with her father or her mother. Of course this suggestion includes the hypothesis that she imagines her perceptions of the husband or boss to be perceptions of her father or mother.

In all of these cases, not only is the actual object of a person's perceptual experience in fact different from what she imagines it to be and not only does she know this to be so, it is likely that the actual intentional content of her experience is different from what she imagines it to be, i.e., the "original experience retains its content" even as she imagines it to have a different content. The sounds produced by the flutist performing Die Zauberflöte seem to the listeners to be just that, while they imagine themselves to be hearing Papageno's playing. 
Wollheim notes that "imagining one experience to be another is something more experiential than simply imagining that one experience is the other." 43 This seems right (or rather it seems right that a more experiential imagining is involved in picture perception). It is not easy to say what "experiential" means here. But the examples of imagining one experience to be another, presented above, seem to me to be appropriately experiential.

If there is some sort of incompatibility between the two intentional contents, why is not this a problem for Wollheim's own notion of seeing-in? Seeing-in is an experience characterized by what he calls "twofoldness": one sees the marked picture surface, and one sees the subject of the picture. These are not two independent experiences, he insists, but two aspects of a single one. It is hard to know what this means, and Wollheim offers little explanation. But he clearly says that we have a "single perceptual experience" involving two different intentional contents. Why doesn't he think the one content interferes with the other? How can the perception of the surface "retain its content" if one succeeds in making the subject of the painting the content of this one's perceptual experience? Well, the experience has two different "aspects." But what does this mean? Wollheim rejects the duck/rabbit analogy, precisely on the grounds that it suggests an incompatibility; one cannot presumably see the figure as a duck and as a rabbit simultaneously. I propose that my theory goes some way toward showing how two different intentional contents can be combined. The experience is a perception of the pictorial surface imagined to be a perception of a fire engine, or of whatever is depicted.

\section{V}

More needs to be said about this experience. I have not fully specified, either here or previously, the nature of the imaginings involved or how they are related to one's actual seeing of the picture surface. But I hope to have shown that imaginings (or whatever one chooses to call them) along the lines I have suggested are an essential ingredient of picture perception, and that Wollheim's worries about supposing this to be so are unfounded. ${ }^{44}$
KENDALL WALTON

Department of Philosophy

University of Michigan

Ann Arbor, Michigan 48109

INTERNET: klwalton@umich.edu

1. Richard Wollheim, "On Pictorial Representation," The Journal of Aesthetics and Art Criticism 56 (1998): 217-233; Richard Wollheim, Painting as an Art: The Andrew W. Mellon Lectures in the Fine Arts (Princeton University Press, 1987). My main contributions to the discussion are Walton, Mimesis as Make-Believe: On the Foundations of the Representational Arts (Harvard University Press, 1990), chap. 8; Walton, "Seeing-In and Seeing Fictionally," in James Hopkins and Anthony Savile, Mind, Psychoanalysis, and Art: Essays for Richard Wollheim (Oxford: Blackwell, 1992), pp. 281-291; and Walton, "Pictures and Photographs: Objections Answered," in Film Theory and Philosophy, ed. Richard Allen and Murray Smith (Oxford: Oxford University Press, 1997), pp. 60-75.

2. Wolheim, "On Pictorial Representation," p. 223.

3. Ibid., p. 223; cf. Wollheim, Painting as an Art: The Andrew W. Mellon Lectures in the Fine Arts, p. 69.

4. There is room for skepticism about this. Perhaps such things can be depicted, misrepresented, as being visible. Robert Hopkins has interesting things to say about this in "Explaining Depiction," The Philosophical Review 104 (1995): 429-431, and Picture, Image and Experience: A Philosophical Inquiry (Cambridge: Cambridge University Press, 1998), p. 168. Cf. Walton, Mimesis as Make-Believe, pp. 229-330.

5. Wollheim, "On Pictorial Representation," p. 223.

6. Perhaps he means to be avoiding this commitment when he says, "Representations that are of things merely of some particular kind" cannot "sustain answers to the question, Which object? Which event? or, Which woman? Which battle?" ("On Pictorial Representation," p. 223.) But the sense in which they cannot is very unclear. These questions invite any number of reasonable answers: "That one," "The one in the picture," "The one so-and-so is now looking at," "The one wearing the fancy hat," "The one looking over her shoulder." Which if any of these answers is informative will of course depend on the context. Whether they are true when taken literally depends on one's theory of fiction. In Painting as an Art, Wollheim notes that "of course, 'This is a picture of Venus' does not admit of existential generalization" (Painting as an Art, p. 361, n.16).

7. The representational content of a painting is "often, and totally misleadingly, referred to as its 'illusionistic' content," Wollheim remarks. And he speaks of "the unjustified assimilation of the representational to the illusionistic or the imitative" (Richard Wollheim, "On Formalism and Pictorial Organization," The Journal of Aesthetics and Art Criticism 59 [2001]: 131-132).

8. Wollheim, Painting as an Art, p. 361, n.21.

9. Ibid., p. 361, n. 21. On my theory, it is fictional in the world of the picture that there are peasants but not that I see them. Both statements express fictional truths in the spectator's game world. Cf. my Mimesis as Make-Believe, pp. 293-304.

10. Those who think that there really is something (the 
woman in the picture) that I imagine seeing still have the problem of saying what sort of thing this is, although they needn't say that it is something that can actually be seen.

11 . There may be no specific mode of cognitive access such that readers imagine knowing about a person in that manner. Nevertheless, they probably imagine that their cognitive access to the person is in some ordinary manner or other.

12. Wollheim, Painting as an Art, pp. 210, 215, 218, 223, and 234-235.

13. Wollheim, "On Pictorial Representation,” p. 221; Paintings as an Art, p. 46.

14. Wollheim, Paintings as an Art, p. 195.

15. In other places, Wollheim might be taken to suggest that perspective is a matter of how things are depicted, although he does not explain what this amounts to. He refers to the "point of origin" from which something is painted (ibid., p. 130). And he speaks of what the picture represents "as it represents it" (ibid.).

16. Wollheim, Paintings as an Art, p. 101; cf. "On Pictorial Representation," p. 225.

17. Wollheim, Paintings as an Art, chap. 3.

18. Ibid., p. 102.

19. Ibid., p. 103.

20. Robert Hopkins (among others) has argued for the plausible thesis that depiction is necessarily from a point of view ("Explaining Depiction," p. 428; Picture, Image and Experience, p. 36), while noting that there can be significant indeterminacies in a picture's perspective. (Ambiguities also, I would add.) Dominic Lopes observes rightly that a picture need not represent things from a single point of view (Lopes, Understanding Pictures [New York: Oxford University Press, 1996], p. 120). I think a picture might conceivably lack a point of view entirely but that this virtually never happens.

21. My point here is essentially the same as that of an example I introduced in another place of two circular films or videos of a roller coaster ride, one made with a camera fixed to the roller coaster and gyrating with it, the other made with a camera remaining rigidly upright. What is portrayed, what the viewer sees in the (moving) picture, is the same in the two cases, but they are sure to affect viewers very differently. Picture perception is not just a matter of ascertaining what is true in the world of the picture, as I put it there, or of what we see in the picture surface, even what we see to be included in the "represented space." The difference between the two films cannot be explained in terms of what we see in them. Cf. Kendall Walton, "Make-Believe, and Its Role in Pictorial Representation and the Acquisition of Knowledge," Philosophic Exchange 23 (1993): 81-95. Reprinted in Aesthetics, ed. Susan Feagin and Patrick Maynard (Oxford University Press, 1997).

22. Mimesis as Make-Believe, pp. 337-348.

23. The thought, if we call it that, need not be involved in a sense that entails that the person articulate it, or say to himself, "I see a woman." But the naturalness of describing one's experience in this way, one's readiness to do so, suggests that the thought, in an unarticulated form, is already there. Robert Hopkins appears to recognize part of what is needed. When you see a horse in a picture, he says, "the thought (or some such) of a horse enters your experience of the picture" (Picture, Image and Experience, p. 16).

24. Wollheim, Painting as an Art, pp. 46-47. Cf. "On Pictorial Representation,” p. 221.
25. Malcolm Budd, "On Looking at a Picture," in Psychoanalysis, Mind and Art: Perspectives on Richard Wollheim, ed. Jim Hopkins and Anthony Savile (Oxford: Blackwell, 1992), p. 271.

26. Wollheim, Painting as an Art, p. 47.

27. Cf., for example, the studies described by Lien B. Pham and Shelley E. Taylor, "From Thought to Action: Effects of Process- Versus Outcome-Based Mental Simulations on Performance," Personality \& Social Psychology Bulletin 25 (1999): 250-260; Roger N. Shepard, "The Mental Image," American Psychologist 33 (1978):125-137; and Shelley E. Taylor, Lien B. Pham, Inna D. Rivkin, and David A. Armor, "Harnessing the Imagination: Mental Simulation, Self-Regulation, and Coping," American Psychologist 53 (1998):429-439. Shepard takes some of his experiments to provide evidence that "the very same mechanisms are operative in imagery as in perception" (ibid., p. 134). Thanks to Gregory Walton for these references.

28. Wollheim claimed that the make-believe theory has "grave difficulties" in accounting for this phenomenon (Paintings as an Art, p. 360, n.8).

29. Jerrold Levinson, "Wollheim on Pictorial Representation," The Journal of Aesthetics and Art Criticism 56 (1998): 227.

30. I will not examine the most obvious difference between Levinson and Wollheim: Levinson rejects the necessity of "twofoldness," which Wollheim has always taken to be at the very heart of his conception of seeing-in.

31. "Wollheim on Pictorial Representation," p. 229, emphasis in original.

32. Jerrold Levinson, "Making Believe," in The Pleasures of Aesthetics (Cornell University Press, 1996), p. 294.

33. "Wollheim on Pictorial Representation," p. 232, n.3, emphasis in original. Wollheim expressly allows for imaginings being involuntary or passive rather than active, and so does not share Levinson's conception of imagining. Cf. Wollheim, "Imagination and Identification," in On Art and the Mind (Harvard University Press, 1974), pp. $69 \mathrm{ff}$.

34. Ibid., p. 227.

35. See Mimesis as Make-Believe, pp. 293-352.

36. Catherine Abell and Gregory Currie, "Internal and External Pictures," Philosophical Psychology 12 (1999): 440-441. I do not know how Currie will square this suggestion with his skeptical remarks in Image and Mind: Film, Philosophy and Cognitive Science (Cambridge: Cambridge University Press, 1995), which I discuss in "On Pictures and Photographs: Objections Answered," in Film Theory and Philosophy, ed. Richard Allen and Murray Smith (Oxford: Oxford University Press, 1997), pp. 60-75.

37. Wollheim, Painting as an Art, pp. 77 and 361, n.21. I responded to this objection in Mimesis as Make-Believe, pp. 301-302. Cf. my exchange with Wollheim in Philosophy and Phenomenological Research 51 (1991), Symposium on Mimesis as Make-Believe, pp. 401-406 and 423-427; and Walton, "Seeing-In and Seeing Fictionally," p. 288. More recently, Wollheim described me as "the major contemporary advocate of the theory that we relate to the content of pictures through the imagination rather than perceptually" ("A Passionate Sightseer," review of Michael Podro, Depiction, in The Times Literary Supplement 23 [April 1999], p. 20). I decline the honor, having designed my theory to establish and explain the fundamentally perceptual nature of pictorial representation. 
38. Walton, Mimesis as Make-Believe, pp. 38 and 40-41. 39. Ibid., pp. 13-16, 23, 68, 139, 185-186, 216, 311, 351-352, and especially 217, 301-302.

40. Richard Wollheim, Art and Its Objects, 2nd ed. (Cambridge: Cambridge University Press, 1980), p. 207. My principles are not tied essentially to artists' intentions, as his standards of correctness are.

41. Wollheim, "On Pictorial Representation," p. 224.

42. If the recording is of an actual concert performance (as many of Gould's recordings are not), in hearing (directly) the sounds from the speakers, I am hearing, indirectly, the actual performance. I imagine my experience to be one of hearing the performance directly. (Cf. my "Transparent Pictures," in Critical Inquiry 11 [1984]: 246-277.)

43. Wollheim, "On Pictorial Representation," p. 225.

44. I am indebted to Malcolm Budd, David Hills, Jerrold Levinson, Patrick Maynard, and Richard Wollheim for discussions of the ideas in this essay. 